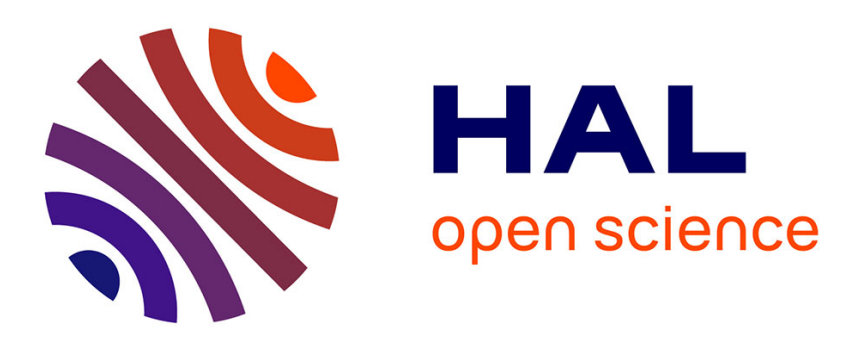

\title{
Desulfovibrio spp. survive within KB cells and modulate inflammatory responses
}

C Bisson-Boutelliez, F. Massin, D. Dumas, N Miller, A. Lozniewski

\section{To cite this version:}

C Bisson-Boutelliez, F. Massin, D. Dumas, N Miller, A. Lozniewski. Desulfovibrio spp. survive within KB cells and modulate inflammatory responses. Molecular Oral Microbiology, 2010, 25 (3), pp.226-35. 10.1111/j.2041-1014.2009.00550.x . hal-02987410

\section{HAL Id: hal-02987410 \\ https://hal.univ-lorraine.fr/hal-02987410}

Submitted on 3 Nov 2020

HAL is a multi-disciplinary open access archive for the deposit and dissemination of scientific research documents, whether they are published or not. The documents may come from teaching and research institutions in France or abroad, or from public or private research centers.
L'archive ouverte pluridisciplinaire HAL, est destinée au dépôt et à la diffusion de documents scientifiques de niveau recherche, publiés ou non, émanant des établissements d'enseignement et de recherche français ou étrangers, des laboratoires publics ou privés.

\section{(c)(1)}

Distributed under a Creative Commons Attribution| 4.0 International License 


\title{
Desulfovibrio spp. survive within KB cells and modulate inflammatory responses
}

\author{
C. Bisson-Boutelliez ${ }^{1,2}$, F. Massin ${ }^{3}$, D. Dumas ${ }^{4}$, N. Miller ${ }^{2}$ and A. Lozniewski ${ }^{1}$ \\ 1 Laboratoire de Bactériologie-UMR CNRS 7565, Faculté de Médecine, Nancy Université, Nancy, France \\ 2 Département de Parodontologie et d'Implantologie, Faculté d'Odontologie, Nancy Université, Nancy, France \\ 3 Laboratoire d'Immunologie, Faculté de Médecine, Nancy Université, Nancy, France \\ 4 UMR CNRS 7563, Faculté de Médecine, Nancy Université, Nancy, France
}

Correspondence: Neal Miller, Département de Parodontologie et d'Implantologie, Faculté d'Odontologie, 96 avenue de Lattres de Tassigny, 54004 Nancy Cedex, France Tel.: + 333838529 52; fax: + 333836829 81; E-mail: neal.miller@odonto.uhp-nancy.fr

Keywords: cytokines; epithelial cells; invasion; periodontal disease

Accepted 1 September 2009

\section{SUMMARY}

Desulfovibrio are sulfate-reducing anaerobic gram-negative rods that have been proposed as potential periodontopathogens. We investigated the capacity of Desulfovibrio to invade epithelial cells and induce cytokine secretion from these cells. Desulfovibrio strains were co-cultured with KB cells and counts of intracellular bacteria evaluated up to 3 days after infection. Desulfovibrio desulfuricans and Desulfovibrio fairfieldensis were able to survive within epithelial cells. Intracytoplasmic location of both bacterial species was confirmed by confocal laser scanning microscopy and transmission electron microscopy. Invasion was sensitive to nocodazole, an inhibitor of microtubule polymerization, but not to cytochalasin $D$, a microfilament inhibitor, suggesting that microtubule rearrangements were involved in the internalization of Desulfovibrio strains by KB cells. Infection by Desulfovibrio resulted in increased production of IL- 6 and IL-8 by KB cells. The ability of $D$. desulfuricans and $D$. fairfieldensis to survive within oral epithelial cells and to modulate the epithelial immune response may contribute to the initiation and progression of periodontal diseases.

\section{INTRODUCTION}

Periodontitis is a multifactorial disease involving complex interactions between various anaerobic bacteria and host cells, which may lead to periodontal tissue destruction. Epithelial cell invasion has been suggested to play an important role in the pathogenesis of periodontitis (Lamont \& Yilmaz, 2002; Colombo et al., 2007; Johnson et al., 2008). Cell invasion may allow periodontopathogens to persist within oral epithelial cells, to evade the immune system, and possibly to disseminate through underlying tissues (Andrian et al., 2004). So far, invasion potential has been shown in vitro and/ or in vivo for several bacteria associated with periodontal diseases, including Aggregatibacter actinomycetemcomitans, Eikenella corrodens, Fusobacterium nucleatum, Prevotella intermedia, Porphyromonas gingivalis, 'Tannerella forsythia', and Treponema denticola (Meyer et al., 1991; Duncan et al., 1993; Dorn et al., 1998; Han et al., 2000; Colombo et al., 2007). While the interaction of all these pathogens with epithelial cells may contribute to the release of inflammatory mediators, it has been shown that the expression of various cytokines, including interleukin-1 $\beta$ (IL-1 $\beta$ ), IL-6, and IL-8, by epithelial cells infected with $P$. gingivalis may be positively correlated with its invasive capacity (Eick et al., 2006). Consequently, epithelial invasion may also have a direct impact on disease progression and the inflammatory processes.

Sulfate-reducing bacteria (SRB) are a diverse group of organisms that are found in the environment 
but may also colonize the digestive tract of animals and humans (Gibson, 1990; Willis et al., 1995; Zinkevich \& Beech, 2000; Boopathy et al., 2002). These organisms have been reported to be the causes of human infections including bacteremia and brain and liver abscesses, and may play a role in inflammatory bowel diseases (Watanabe et al., 2007; Rowan et al., 2009). Recent findings suggest that SRB may also be involved in periodontitis (Langendijk et al., 1999, 2000; Langendijk-Genevaux et al., 2001; Boopathy et al., 2002; Loubinoux et al., 2002; Vianna et al., 2008). Different isolates of SRB have been isolated from the oral cavity, generally belonging to the genus Desulfovibrio (Langendijk et al., 2001; Boopathy et al., 2002; Loubinoux et al., 2002). So far, Desulfovibrio fairfieldensis and, to a lesser extent, Desulfovibrio desulfuricans, are the two Desulfovibrio species that have been isolated from the oral cavity (Beerens \& Tahon-Castel, 1965; Loubinoux et al., 2002). However, their role in the pathogenesis of periodontitis remains unclear. To further investigate the potential pathogenic role of $D$. fairfieldensis and $D$. desulfuricans, we studied their potential ability to invade non-professional phagocytic cells and their capacity to induce inflammatory responses from these cells.

\section{METHODS}

\section{Bacterial strains and tissue culture conditions}

Strains used in this study were obtained from the American Type Culture Collection (ATCC, Rockville, MD): D. desulfuricans ATCC 29577, D. desulfuricans ATCC 27774, D. fairfieldensis ATCC 700045, and $P$. gingivalis ATCC 33277. All strains were stored at $-80^{\circ} \mathrm{C}$ in Brucella broth containing $15 \%$ glycerol (weight/volume). Before testing, bacteria were grown anaerobically at $37^{\circ} \mathrm{C}$ on Brucella agar supplemented with $5 \%$ defibrinated sheep blood, for $24 \mathrm{~h}$ for $P$. gingivalis ATCC 33277 and $72 \mathrm{~h}$ for the Desulfovibrio strains.

The KB cell line ATCC CCL-17 (HeLa cells) was routinely cultured in flasks under a humidified atmosphere containing $5 \% \quad \mathrm{CO}_{2}$ at $37^{\circ} \mathrm{C}$ in RPMI-1640 medium (Gibco, Invitrogen, Cergy Pontoise, France) supplemented with $10 \%$ fetal calf serum, $1 \%$ l-glutamine (Gibco), $16 \mu \mathrm{g} \mathrm{ml}^{-1}$ amikacin, and $128 \mu \mathrm{g} \mathrm{ml}^{-1}$ amoxicillin.

\section{Invasion assay}

Invasion of epithelial cells was determined using an antibiotic protection and invasion assay as previously described by Han et al. (2000). For each strain, plate cultures were harvested, washed twice in phosphatebuffered saline (PBS) and suspended in unsupplemented cell culture medium at a concentration of $5 \times 10^{7}$ cells $\mathrm{ml}^{-1}$ determined by optical density. Bacterial suspensions $(1 \mathrm{ml})$ were added to confluent $\mathrm{KB}$ monolayers (multiplicity of infection 100 bacteria per cell) in 24-well plates. After $2 \mathrm{~h}$ of incubation at $37^{\circ} \mathrm{C}$, unattached bacteria were removed by three washes with unsupplemented RPMI-1640 medium. External adherent cells were killed by incubating the infected monolayers with fresh medium containing metronidazole $\left(200 \mu \mathrm{g} \mathrm{m}^{-1}\right)$ and gentamicin $\left(300 \mu \mathrm{g} \mathrm{m}^{-1}\right)$ for $1 \mathrm{~h}$. The cell culture medium was removed and cells were washed three times with PBS. Intracellular bacteria were then released by lysis of the cells in sterile distilled water for $20 \mathrm{~min}$. To assess intracellular persistence and multiplication of Desulfovibrio, monolayers infected with D. fairfieldensis ATCC 700045 and D. desulfuricans ATCC 29577 were further incubated in antibiotic-free and fetal calf serum-free medium for 24, 48, and $72 \mathrm{~h}$. Before cell lysis, 0.1-ml aliquots of the supernatant were sampled and examined for the presence of extracellular bacteria. Serial dilutions of the lysates were performed in sterile $0.9 \% \mathrm{NaCl}$, and $0.1-\mathrm{ml}$ aliquots of the dilutions were plated onto Brucella agar. Bacterial counts were expressed as colony-forming units (CFU) per well.

\section{Inhibitor assays of internalization}

Inhibitor assays were performed using cytochalasin D (Sigma, Saint Quentin Fallavier, France), an actin microfilament polymerization inhibitor, and nocodazole (Sigma), a microtubule polymerization inhibitor. Stock solutions of inhibitors were prepared in dimethylsulfoxide and frozen at $-20^{\circ} \mathrm{C}$ before assays. These solutions were diluted in unsupplemented RPMI-1640 to obtain final assay concentrations of $1 \mu \mathrm{g} \mathrm{ml}^{-1}$ nocodazole and $10 \mu \mathrm{g} \mathrm{ml}^{-1}$ cytochalasin $\mathrm{D}$. The KB cells were incubated with cytochalasin $D$ for $30 \mathrm{~min}$ before bacterial contamination. Nocodazole was added to the monolayers for $1 \mathrm{~h}$ on ice, and then warmed to $37^{\circ} \mathrm{C}$ for $30 \mathrm{~min}$ before the addition of bacteria. Each inhibitor was present during the assay. 
The invasion assay was conducted as previously described. For each Desulfovibrio strain tested, intracellular viable counts were determined at $2 \mathrm{~h}$ postinfection. At the concentrations used, inhibitors affected neither the viability of epithelial cells, as determined by examining the confluency of the monolayers and by trypan blue exclusion, nor the viability of bacterial strains as assessed by viable cell counting.

\section{Electron microscopy}

For each Desulfovibrio strain tested, ultrastructural studies of KB cells were performed at $2 \mathrm{~h}$ postinfection using transmission electron microscopy. Infected cell monolayers were fixed with $2.5 \%$ glutaraldehyde in $0.1 \mathrm{~m}$ cacodylate buffer $(\mathrm{pH} 7.4)$. Following rinses with cacodylate buffer, the samples were postfixed for $1 \mathrm{~h}$ in $0.1 \mathrm{~m}$ cacodylate buffer containing $1 \%$ osmium tetroxide. The monolayers were dehydrated using increasing concentrations of ethanol [30, 50, 70,80 , and $90 \%$ (5 min for each step), $100 \%$ (20 min, three times)], and three changes of propylene oxide (20 min for each step). The samples were placed in a propylene oxide-epoxy resin (Epikote 812; Consortium International Pharmaceutique et Chimique, Paris, France) for $1 \mathrm{~h}$ at room temperature before being placed in $100 \%$ epoxy resin overnight as described by Luft et al. (1961). Then, they were embedded in fresh epoxy resin for $3 \mathrm{~d}$ at $56^{\circ} \mathrm{C}$. Ultrathin sections were cut on a Reichert $\mathrm{OMU}_{3}$ ultramicrotome using a diamond knife, collected on copper grids, and stained with uranium acetate and Reynold's lead citrate. Sections were observed using a Philips CM12 M at $80 \mathrm{kV}$.

\section{Generation of antibodies}

Desulfovibrio fairfieldensis ATCC 700045 was cultured as previously described on supplemented Brucella blood agar for $72 \mathrm{~h}$. Bacterial cells were washed three times with PBS, resuspended in sterile $0.9 \% \mathrm{NaCl}$ at a final concentration of $10^{8}$ cells $\mathrm{ml}^{-1}$ and finally inactivated using ultraviolet light. Inactivated bacteria were sent to Covalab Laboratory (Lyon, France) for the generation of polyclonal antibodies in rabbits. Specificity of the immune serum was evaluated by indirect immunofluorescence on D. fairfieldensis ATCC 700045, D. desulfuricans
ATCC 29577, P. gingivalis ATCC 33277, F. nucleatum Roger, Prevotella intermedia ATCC 25611, and Prevotella buccae ATCC 33574 . Briefly, a $50-\mu$ l sample of cell suspension of each strain was spotted onto a slide for immunofluorescence tests, air dried, and fixed in cold ethanol. Smears were incubated with antiserum used at dilutions of $1: 100,1: 200$, or $1: 500$ for $30 \mathrm{~min}$ at $37^{\circ} \mathrm{C}$ in a moist chamber. After three washes in PBS, fluorescein isothiocyanate (FITC) -conjugated goat anti-rabbit immunoglobulin G antibody (Sigma) was added and incubated for another $30 \mathrm{~min}$. After being washed with PBS, slides were examined with an Olympus fluorescence microscope at $\times 400$ magnification. Specific reactivity was observed up to a dilution of $1: 500$ for both Desulfovibrio strains. No cross-reactivity was found with any of the other strains tested.

\section{Confocal scanning laser microscopy}

KB cells were seeded in eight-well Labteck II chambers (Nunc, Dutscher, France) at a concentration of $5 \times 10^{4}$ cells well $^{-1}$ and incubated for $48 \mathrm{~h}$. Before infection, KB cells were stained with $2 \mu \mathrm{m}$ 1'-di-octadecyl 3,3,3',3'-tetramethylindocarbocyanine perchlorate $\left(\right.$ DilC $\left._{16}\right)$ (Molecular Probe, Invitrogen, Cergy Pontoise, France) in RPMI-1640 for 2 min. DilC $_{16}$ is a lipophilic carbocyanine membrane probe suitable for labeling cell surface membranes as well as intracytoplasmic membranes (Mukherjee et al., 1999). Invasion assays were performed with $D$. fairfieldensis ATCC 700045 and D. desulfuricans ATCC 29577 as described above. At $2 \mathrm{~h}$ postinfection, cells were washed three times with unsupplemented RPMI-1640 medium and fixed in $2 \%$ paraformaldehyde at $4^{\circ} \mathrm{C}$ for $15 \mathrm{~min}$. After three washes with PBS, cell monolayers were permeabilized with $0.1 \%$ Triton $\mathrm{X}-100$ for $5 \mathrm{~min}$. Cells were washed twice and incubated in PBS containing $5 \%$ bovine serum albumin (Sigma) for $20 \mathrm{~min}$ at room temperature (Kuehnel et al., 2001). After removing the supernatant, cells were incubated overnight with rabbit anti-Desulfovibrio serum diluted at $1: 200$. Cells were then incubated with an FITC-conjugated goat anti-rabbit immunoglobulin G $(1: 100)$ (Sigma) for $45 \mathrm{~min}$ followed by Alexa Fluor 488 anti-FITCconjugated rabbit polyclonal immunoglobulin $G$ (1: 100) (Molecular Probe) for $45 \mathrm{~min}$. Samples were observed with a confocal scanning laser 
microscope (CLSM) SP2-AOBS (Leica Microsystems, Wetzlar, Germany), constituted by an inverted epifluorescence microscope equipped with an argon laser source at $488 \mathrm{~nm}$ and a helium/neon laser at $543 \mathrm{~nm}$. The intensity of the fluorescence signal was measured between 500 and $520 \mathrm{~nm}$ for Alexa 488 (coded in green) and between 520 and $580 \mathrm{~nm}$ for Dil (coded in red) with $\mathrm{a} \times 63$ objective (water immersion/1.32 NA). For each frame, the collection of fluorescence signal was adjusted spectrally to avoid the overlapping of the two emission dyes with a sequential mode. Different controls were achieved to eliminate non-specific detections. Uninfected cells with antibodies I, II, and III, and infected cells with antibodies II, III were used as negative controls to determine the threshold value of positive detection. Images were achieved with a z-step of $0.2 \mu \mathrm{m}$ with a format of $512 \times 512$ pixels, $400 \mathrm{~Hz}$, and analysed with Leica software Ics. Images were pseudocolored according to their respective emission and overloaded with Leica/Metamorph software.

\section{Cytokine induction assay}

Culture media from 24, 48, and $72 \mathrm{~h}$ infected or uninfected KB cells were collected at the end of the experiments and stored at $-20^{\circ} \mathrm{C}$ until assayed using enzyme-linked immunosorbent assay kits for IL-1 $\beta$, IL-8 (RayBio, Norcross, GA), and IL-6 (Bender Medsystems, Vienna, Austria). Samples were processed according to the manufacturer's instructions. Plates were read at $450 \mathrm{~nm}$ using a microplate reader (Sunrise, Tecan, Lyon, France). The detection levels were 3, 8, and $0.98 \mathrm{pg} \mathrm{ml}^{-1}$ for IL-1 $\beta$, IL-8, and IL-6, respectively. Cytokine concentrations were determined in triplicate by comparison with a standard curve prepared for each kit. Data were presented as means \pm SD. Cytokine levels were compared using the unpaired Student's t-test (Graph Pad Software, San Diego, CA). Significances were defined as having $P<0.05$.

\section{RESULTS}

\section{Entry and survival of Desulfovibrio in KB cells}

Two hours after infection, all three Desulfovibrio strains tested exhibited similar invasion efficiencies
Table 1 Comparison of invasion of KB cells by Desulfovibrio spp. and Porphyromonas gingivalis

\begin{tabular}{ll}
\hline Strain & $\begin{array}{l}\text { CFU well }^{-1} \text { recovered after } \\
\text { antimicrobial treatment }^{1}\end{array}$ \\
\hline D. fairfieldensis ATCC 700045 & $(1.53 \pm 0.6) \times 10^{4}$ \\
D. desulfuricans ATCC 29577 & $(6.5 \pm 2) \times 10^{4}$ \\
D. desulfuricans ATCC 27774 & $(3.81 \pm 0.44) \times 10^{4}$ \\
$P$. gingivalis ATCC 33277 & $(3.86 \pm 0.17) \times 10^{5}$ \\
\hline
\end{tabular}

CFU, colony-formig units.

${ }^{1}$ Values represent the means \pm standard deviations from quadruplicate independent determination $2 \mathrm{~h}$ postinfection.

as assessed by the antibiotic protection assay (Table 1). However, the invasion efficiency of these strains $(0.05-0.13 \%$ of the initial inoculum) was lower than those observed with $P$. gingivalis ATCC 33277 $(0.69 \%$ of the initial inoculum), which was used as a positive control (Houalet-Jeanne et al., 2001). For D. fairfieldensis ATCC 700045, the mean number of internalized viable bacteria was 3.5 times higher $(P<0.01)$ at $24 \mathrm{~h}$ postinfection than at $2 \mathrm{~h}$ postinfection, suggesting intracellular replication (Fig. 1). Thereafter, the viable intracellular counts gradually decreased $(P<0.01)$ down to about $57 \%$ of the initial intracellular count at $72 \mathrm{~h}$ postinfection. Similar results were found, as expected (Houalet-Jeanne et al., 2001), for P. gingivalis ATCC 33277. For D. desulfuricans ATCC 29577, a statistically significant twofold increase $(P<0.01)$ of the mean number of viable intracellular bacteria occurred at $48 \mathrm{~h}$. Thereafter, the intracellular counts decreased but remained slightly higher than those found at $2 \mathrm{~h}$ postinfection. The numbers provide evidence of an intracellular replication for D. fairfieldensis ATCC 700045 and a similar pattern is apparent for $D$. desulfuricans ATCC 29577 although the bacterial proliferation starts somewhat later. At no time, did the supernatant counts exceed $7 \%$ of the intracellularly recovered bacteria.

\section{Tubulin-dependent KB cells invasion by Desulfovibrio strains}

Entry of bacteria into host cells requires microtubule or microfilament rearrangements (Meyer et al., 1997). To assess whether internalization of Desulfovibrio strains is actin- and/or tubulin-dependent, we evaluated the effects of cytochalasin $D$ and nocodazole 


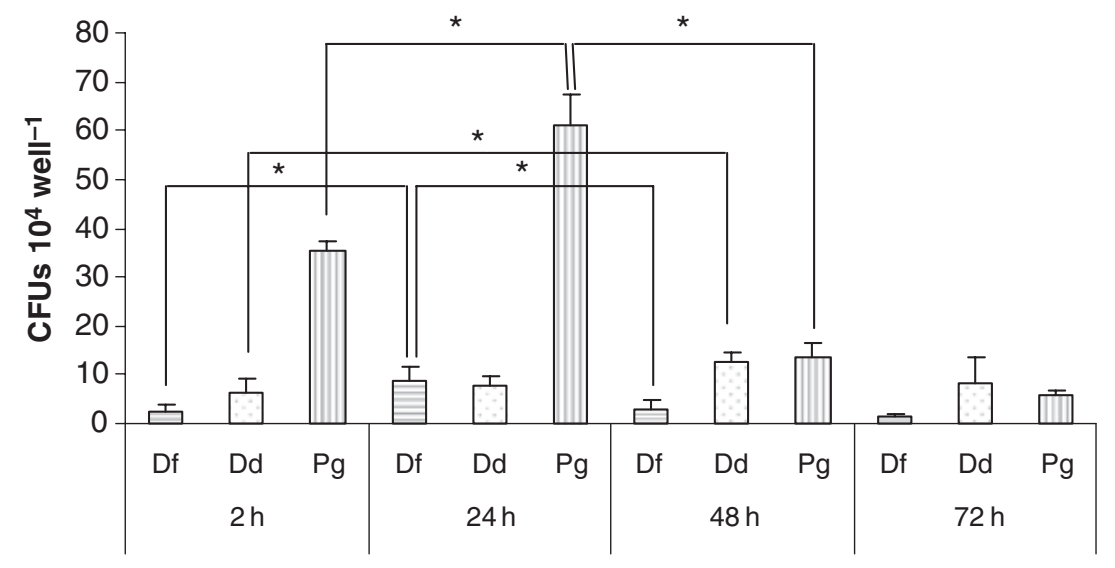

Figure 1 Intracellular viability of Desulfovibrio desulfuricans ATCC 29577, Desulfovibrio fairfieldensis, and Porphyromonas gingivalis ATCC 33277. Values represent the means \pm $\mathrm{SD}$ from triplicate independent determinations at 2, 24, 48, and $72 \mathrm{~h}$ postinfection. Differences are statistically significant between connected values $\left({ }^{\star} P<0.01\right)$.
Table 2 Effects of metabolic inhibitors on invasion of KB cells by Desulfovibrio desulfuricans and Desulfovibrio fairfieldensis

\begin{tabular}{llc}
\hline & $\begin{array}{l}\text { Percentage of invasion after } \\
\text { treatment by }\end{array}$ \\
\cline { 2 - 3 } Strains & Nocodazole & Cytochalasin D \\
\hline D. fairfieldensis ATCC 700045 & $23.3 \pm 3.8$ & $237.5 \pm 39.2$ \\
D. desulfuricans ATCC 29774 & $52.6 \pm 1.9$ & $138.3 \pm 11.6$ \\
D. desulfuricans ATCC 27774 & $10.7 \pm 1.8$ & $139.6 \pm 11$ \\
\hline
\end{tabular}

Values represent the means \pm standard deviations from triplicate independent determination $2 \mathrm{~h}$ postinfection.

${ }^{1}$ The level of invasion was expressed as a percentage of the control level without any inhibitor.

pretreatment of $\mathrm{KB}$ cells on the internalization of the three Desulfovibrio strains tested. Treatment of the $\mathrm{KB}$ cells with cytochalasin $\mathrm{D}$ resulted in increased numbers of internalized organisms at $2 \mathrm{~h}$ postinfection (Table 2). In contrast, for all three Desulfovibrio strains tested, the counts of internalized viable bacteria at $2 \mathrm{~h}$ postinfection were lower in nocodazole-pretreated KB cells than in control cells, indicating that microtubule formation was required for cell invasion.

\section{Intracytoplasmic localization of Desulfovibrio in KB cells}

Once inside host cells, invasive bacteria replicate within endosomal organelles or escape from the endosomal pathway to the cytoplasm. At $2 \mathrm{~h}$ postinfection, TEM examination of KB cells infected with either $D$. fairfieldensis or $D$. desulfuricans showed that numerous bacteria adhered to the cell surface

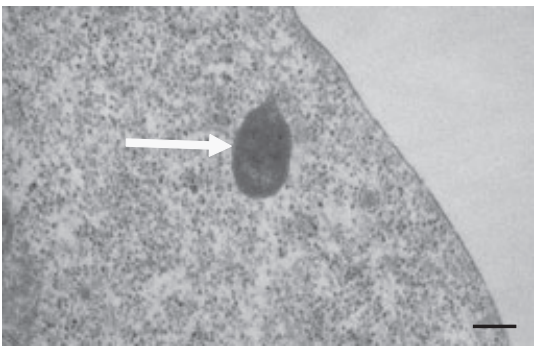

Figure 2 Transmission electron micrograph of Desulfovibrio desulfuricans ATCC 29577 (arrow) inside the cytoplasm of a KB cell, at $2 \mathrm{~h}$ postinfection. Bar: $1 \mu \mathrm{m}$.

while all observed intracellular bacteria appeared to be free in the cytoplasm without surrounding membranes (Fig. 2). The intracytoplasmic localization of both organisms tested was further confirmed by using confocal microscopy. Indeed, while numerous immunolabeled bacteria were shown to adhere to the epithelial cell surface $2 \mathrm{~h}$ postinfection, a few bacteria could be visualized within the cytoplasm of KB cells (Fig. 3). Internalized bacteria could be clearly differentiated from adherent bacteria by superimposing FITC-Alexia 488 and Dil images of serial sections $(0.2 \mu \mathrm{m})$. No colocalization of intracellular immunolabeled bacteria with intracytoplasmic Dil-stained vesicles was observed suggesting that the observed intracellular bacteria were free in the cytoplasm.

\section{Production of cytokines by infected KB cells}

The levels of IL-1 $\beta, I L-6$, and IL- 8 secreted by KB cells after infection with D. desulfuricans 29577 ATCC and D. fairfieldensis ATCC 700045 were also 
Figure 3 Invasion of KB cell by Desulfovibrio fairfieldensis ATCC 700045 visualized by CSLM. (A) D. fairfieldensis were stained green (arrow); (B) intracytoplasmic vesicles stained with Dil appeared red; (C) digital overlapping of images (A) and (B). No vesicles were colocalized with intracytoplasmic bacteria.
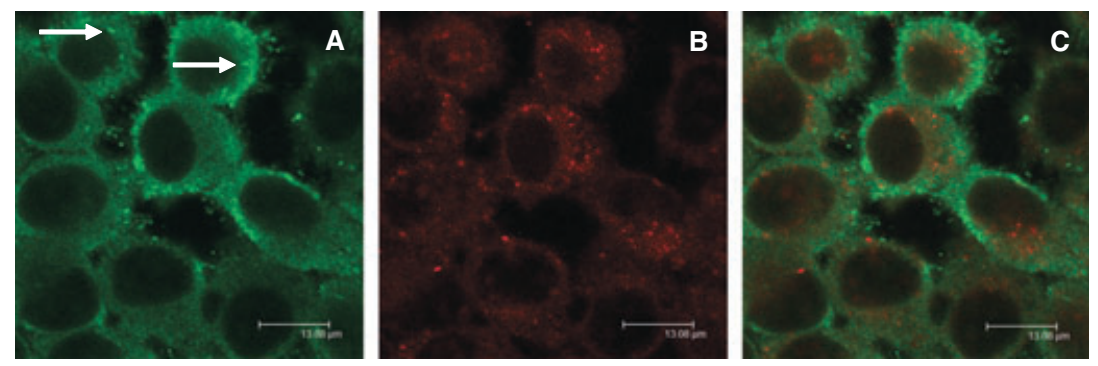

measured. KB cells secreted significantly higher amounts of IL-8 at $2 \mathrm{~h}$ after infection with $D$. fairfieldensis ATCC $700045\left(642 \pm 65 \mathrm{pg} \mathrm{ml}^{-1}\right)$ or $D$. desulfuricans 29577 ATCC $\left(744 \pm 121 \mathrm{pg} \mathrm{ml}^{-1}\right)$ than uninfected $\mathrm{KB}$ cells $\left(356 \pm 73 \mathrm{pg} \mathrm{ml}^{-1}\right)$ (Fig. 4). This difference was no longer observed at 24,48 , and $72 \mathrm{~h}$ after infection with any of the strains tested. No IL-6 was detected in the supernatants of uninfected or infected cells at the 2-h time-point. KB cells constitutively expressed low levels of IL- 6 at $24 \mathrm{~h}$ $\left(2 \pm 0.6 \mathrm{pg} \mathrm{ml}^{-1}\right), 48 \mathrm{~h}\left(2.4 \pm 0.9 \mathrm{pg} \mathrm{ml}^{-1}\right)$, and $72 \mathrm{~h}$ $\left(4.48 \pm 1.9 \mathrm{pg} \mathrm{ml}^{-1}\right)$. In contrast, the amount of IL-6 released from KB cells infected with $D$. desulfuricans ATCC 29577 was significantly increased compared with the control cells at $24 \mathrm{~h}\left(4.1 \pm 0.4 \mathrm{pg} \mathrm{ml}^{-1}\right)$ and $48 \mathrm{~h} \quad\left(5.7 \pm 0.7 \mathrm{pg} \mathrm{ml}^{-1}\right)$ (Fig. 5). When compared with uninfected cells, an increase, although not statistically significant, of IL-6 production was also observed for KB cells at $24 \mathrm{~h}\left(4.2 \pm 1.5 \mathrm{pg} \mathrm{ml}^{-1}\right)$ and $48 \mathrm{~h}\left(4.7 \pm 1.2 \mathrm{pg} \mathrm{ml}^{-1}\right) \quad(P=0.07)$ after infection with $D$. fairfieldensis ATCC 700045 . For both strains, IL-1 $\beta$ concentrations in supernatants from infected KB cells were found to be similar at each time-point studied to those measured in supernatants from control uninfected cells.

\section{DISCUSSION}

In the present study, we have shown that two putative periodontopathogens, D. fairfieldensis and $D$. desulfuricans, have the ability to invade oral epithelial cells. The intracellular location of $D$. fairfieldensis ATCC 700045 and D. desulfuricans ATCC 29577 was confirmed by both TEM and CSLM examination of infected monolayers. For these strains, 0.05$0.13 \%$ of the total number of bacteria initially added were recovered intracellularly at $2 \mathrm{~h}$ postinfection. For $P$. gingivalis ATCC $33277,0.69 \%$ of the initial inoculum was recovered after lysis of the infected KB cells, which is very close to the $0.6 \%$ obtained by
Figure 4 Secretion of interleukin-8 (IL-8) by $\mathrm{KB}$ cells at 2, 24, 48, and $72 \mathrm{~h}$ after infection with Desulfovibrio desulfuricans ATCC 29577 (Dd) and Desulfovibrio fairfieldensis ATCC 700045 (Df). The bars indicate the means and the standard deviations from three independent experiments. Statistically significant $(P<0.01)$ induction of cytokine production compared with control epithelial cells (C).

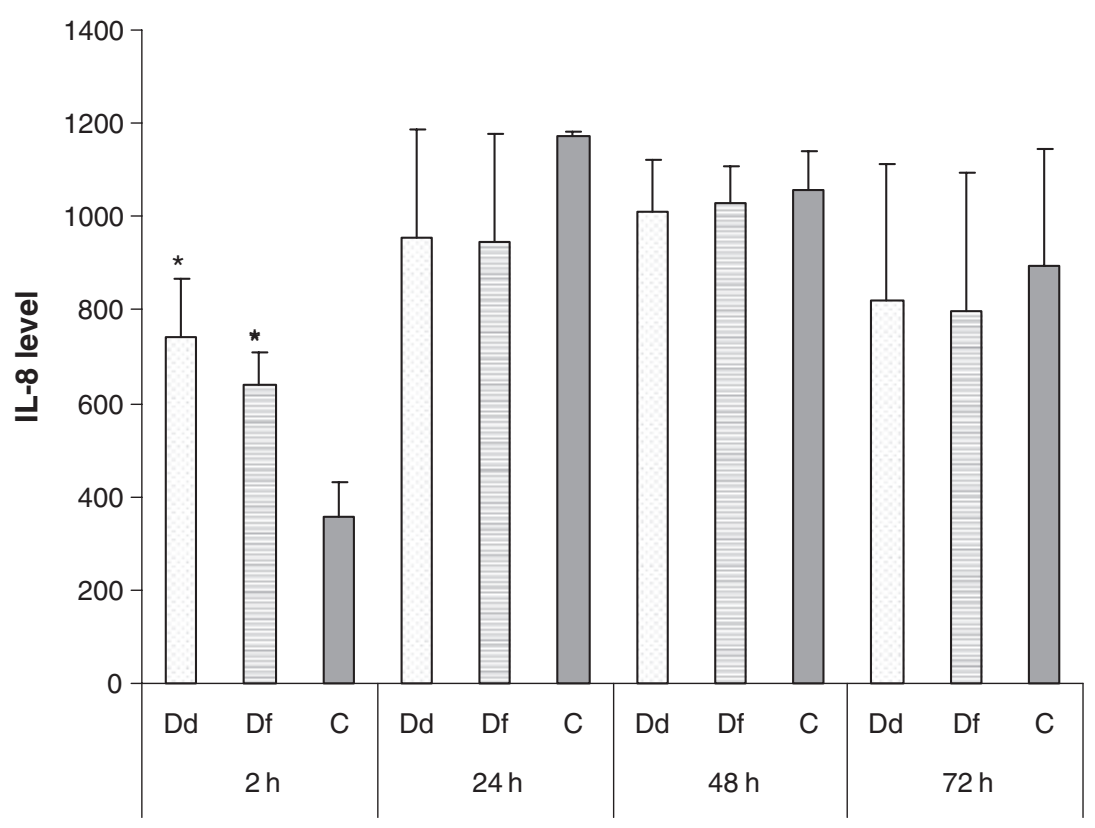




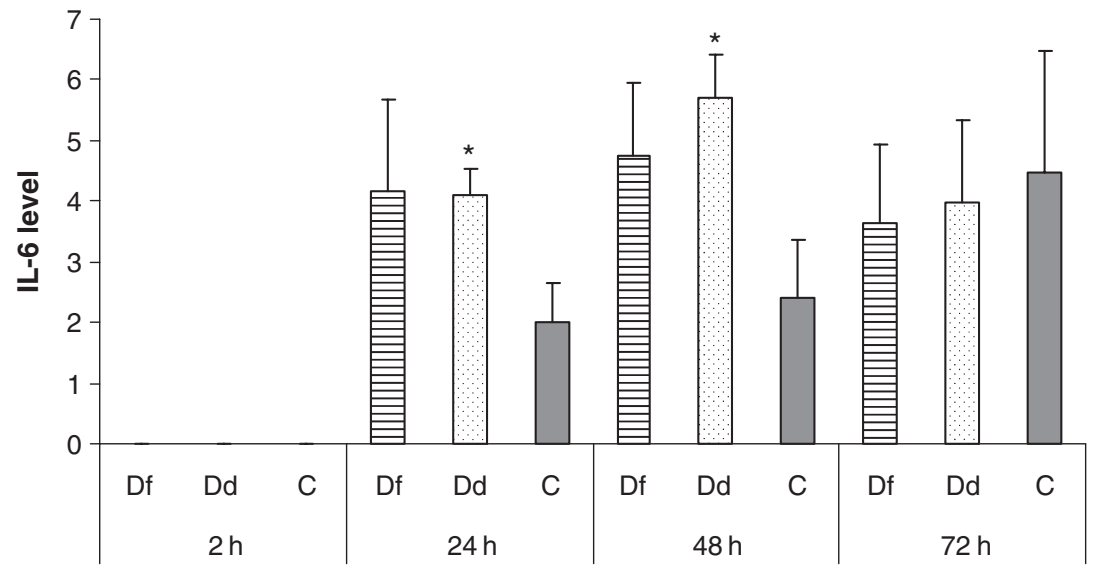

Figure 5 Secretion of interleukin-6 (IL-6) by $\mathrm{KB}$ cells at 2, 24, 48, and $72 \mathrm{~h}$ after infection with Desulfovibrio desulfuricans ATCC 29577 (Dd) and Desulfovibrio fairfieldensis ATCC 700045 (Df). The bars indicate the means and the standard deviations from three independent experiments. Statistically significant $(P<0.01)$ induction of cytokine production compared with control epithelial cells (C).
Houalet-Jeanne et al. (2001) who examined the invasive potential of this isolate using similar experimental conditions. In our study, early internalization levels observed with $D$. fairfieldensis and $D$. desulfuricans were 5- to 15-fold lower than those observed with $P$. gingivalis. However, to investigate the possibility that invasion profiles are strain-specific more strains need to be evaluated. Similar levels of internalization were reported by Han et al. (2000) for another putative periodontopathogen, $P$. intermedia, the invasion level of which has been reported as being 1/20 of that of $P$. gingivalis 381 and $F$. nucleatum 12230. Consequently, the Desulfovibrio spp. strains tested appeared to be weakly invasive. However, it cannot be ruled out that other more invasive Desulfovibrio strains may exist or that interactions with other oral bacteria may enhance the invasion potential of Desulfovibrio as shown for ' $T$. forsythia' interacting with $P$. gingivalis (Inagaki et al., 2006). Also, it must be stressed that KB cells, which are transformed cells, are less efficient than epithelial cells from primary gingival tissue cultures (Belton et al., 2004).

As previously reported by Houalet-Jeanne et al. (2001), we also observed that for $P$. gingivalis ATCC 33277 , the number of intracellular viable bacteria increased about 1.5-fold at $24 \mathrm{~h}$ postinfection in infected KB cells. Quite similar results were also reported with another $P$. gingivalis strain ( $P$. gingivalis FDC381) by Madianos et al. (1996), suggesting that $P$. gingivalis has the ability to multiply within $\mathrm{KB}$ cells. This could be of great clinical importance because Johnson et al. (2008) have demonstrated the presence of $P$. gingivalis within buccal epithelial cells. This suggests a mechanism by which bacteria might be protected from the host response and antimicro- bial therapy, enabling them to re-colonize debrided sites and perhaps contribute to the onset of refractory disease. Likewise, host cells could constitute a reservoir of Desulfovibrio. In the present study, the average number of intracellular viable bacteria increased during the first $24 \mathrm{~h}$ for $D$. fairfieldensis ATCC 700045 and during the first $48 \mathrm{~h}$ for $D$. desulfuricans ATCC 29577. These findings suggest that Desulfovibrio is able to multiply within KB cells. Preliminary experiments permitted us to ensure that the antibiotic concentrations used were effective in killing the entire bacterial inoculum within $1 \mathrm{~h}$ and that supernatant bacterial counts remained low $(\leq 7 \%$ of the intracellular counts) during the whole study period. Therefore, the possibility of an invasion artefact is unlikely. However, the fact that some intracellular organisms may exit the initially infected cells and then enter and multiply in new cells, as shown for other periodontopathogens invading oral epithelial cells such as $P$. gingivalis and A. actinomycetemcomitans (Meyer et al., 1999; Yilmaz et al., 2006), cannot be ruled out and needs further study.

In our study, TEM examination revealed that, at $2 \mathrm{~h}$ postinfection, all intracellular Desulfovibrio organisms appeared free within the cell cytoplasm. Moreover, colocalization of intracellular bacteria within intracytoplasmic vesicles was not found, suggesting that Desulfovibrio may escape the vacuole in early stages of invasion as described for other pathogens (Meyer et al., 1997; Houalet-Jeanne et al., 2001).

For many bacterial pathogens, internalization by epithelial cells is dependent on rearrangements of the actin skeleton. Additionally, some pathogenic bacteria enter epithelial cells via a microtubule- 
dependent mechanism (Yoshida \& Sasakawa, 2003). Among periodontopathogens, $P$. gingivalis and $F$. nucleatum have been shown to enter epithelial cells via both a microtubule-dependent and actin-dependent mechanism (Lamont et al., 1995; Han et al., 2000). It has also been reported that a few strains of $A$. actinomycetemcomitans utilize microtubule-dependent mode of invasion whereas most strains use an actin-dependent mode of entry into epithelial cells (Brissette \& Fives-Taylor, 1999; Meyer et al., 1999). In the present study, treatment with nocodazole, a microtubule-destabilizing agent, resulted in a significant inhibition of bacterial invasion whereas internalization was enhanced in cells pretreated with cytochalasin D. These data suggest that internalization of all three Desulfovibrio strains tested was microtubule-dependent. It is noteworthy that invasion of these strains was increased by cytochalasin D. Similar observations were reported for other organisms that require microtubule rearrangement for invasion. This may be related to the fact that cytochalasin $D$ enhances lysosomal movement to the cell periphery and hence invasion because of the lysosome recruitment and fusion at the plasma membrane (Tardieux et al., 1992).

Besides bacterial internalization, inflammation appears to be another important factor that may be involved in the progression of periodontal infections and local tissue destruction. It has been shown that the production of various cytokines, including IL- 6 and IL-8, by oral epithelial cells following stimulation by periodontopathogens is an early event which participates in the cascade of events leading to inflammation and tissue destruction, and hence is critical for the progression of periodontitis (Graves, 2008). In vitro studies have suggested that cytokine production by epithelial cells may be triggered by their invasion by various bacterial pathogens including $P$. gingivalis (Sandros et al., 2000; Eick et al., 2006). Weglarz et al. (2007) demonstrated that $D$. desulfuricans has the ability to induce the secretion of IL-6 and IL-8 from the human colon cell line Caco-2. In our study, both Desulfovibrio strains tested stimulated the production of these cytokines by KB cells. A significant increase in IL-8 secretion by epithelial cells was observed at $2 \mathrm{~h}$ postinfection. This effect may be the result of various mechanisms triggered by bacterial adhesion or invasion and may play a role in the local immune response as IL-8 acts as a chemokine directing neutrophil migration to the infectious site. It cannot be excluded that soluble products from Desulfovibrio strains directly stimulated epithelial cells and induced upregulation of IL-8, as described for E. corrodens (Yumoto et al., 2007). In contrast, increased production of IL-6 was only detected at 24 and $48 \mathrm{~h}$ after infection with $D$. desulfuricans ATCC 29577 and, to a lesser extent, with D. fairfieldensis ATCC 700045, suggesting that this epithelial response might be more predominantly associated with the presence of intracellular bacteria. IL-6 has also been identified as a periodontal disease marker and its release by host cells may participate in the inflammatory reaction as well as in tissue destruction via the activation of osteoclasts (Moreira et al., 2007; Herman et al., 2008).

In conclusion, this study provides the first evidence that $D$. fairfieldensis and $D$. desulfuricans, two putative periodontopathogens, may invade oral epithelial cells via a microtubule-dependent process. We have also shown that, once inside the cells, these bacteria had the capacity to remain viable for prolonged periods and were able to elicit a minor host cell response that may contribute to the development of periodontal disease. Further studies of these bacterium-host cell interactions are necessary to increase our insight into the role of sulfate-reducing bacteria in periodontitis.

\section{REFERENCES}

Andrian, E., Grenier, D. and Rouabhia, M. (2004) In vitro models of tissue penetration, destruction by Porphyromonas gingivalis. Infect Immun 72: 4689-4698.

Beerens, H. and Tahon-Castel, M. (1965) Infections Humaines à Bactéries Anaérobies non Toxinogènes. Brussels: Presses Académiques Européennes.

Belton, C.M., Goodwin, P.C., Fatherazi, S., Schubert, M.M., Lamont, R.J. and Izutsu, K.T. (2004) Calcium oscillations in gingival epithelial cells infected with Porphyromonas gingivalis. Microbes Infect 6: 440447.

Boopathy, R., Robichaux, M., LaFont, D. and Howell, M. (2002) Activity of sulphate reducing bacteria in human periodontal pocket. Can J Microbiol 48: 10991103.

Brissette, C.A. and Fives-Taylor, P.M. (1999) ActinobacilIus actinomycetemcomitans may utilize either actindependent or actin-independent mechanisms of invasion. Oral Microbiol Immunol 14: 137-142. 
Colombo, A.V., da Silva, C.M., Haffajee, A. and Colombo, A.P.V. (2007) Identification of intracellular oral species within human crevicular epithelial cells from subjects with chronic periodontitis by fluorescence in situ hybridization. J Periodontal Res 42: 236-243.

Dorn, B.R., Leung, K.P. and Progulske-Fox, A. (1998) Invasion of human oral epithelial cells by Prevotella intermedia. Infect Immun 66: 6054-6057.

Duncan, M.J., Nakao, S., Skobe, Z. and Xie, H. (1993) Interaction of Porphyromonas gingivalis with epithelial cells. Infect Immun 61: 2260-2265.

Eick, S., Reissmann, A., Rödel, J., Schmidt, K.H. and Pfister, W. (2006) Porphyromonas gingivalis survives within KB cells and modulates inflammatory response. Oral Microbiol Immunol 21: 231-237.

Gibson, G.R. (1990) Physiology and ecology of sulphatereducing bacteria. J Appl Bacteriol 69: 769-797.

Graves, D. (2008) Cytokines that promote periodontal tissue destruction. J Periodontol 79: 1585-1591.

Han, Y.W., Shi, W., Huang, G.T.J. et al. (2000) Interactions between periodontal bacteria and human oral epithelial cells: Fusobacterium nucleatum adheres to and invades epithelial cells. Infect Immun 68: 3140-3146.

Herman, S., Krönke, G. and Schett, G. (2008) Molecular mechanisms of inflammatory bone damage: emerging targets for therapy. Trends Mol Med 14: 245-253.

Houalet-Jeanne, S., Pellen-Mussi, P., Tricot-Doleux, S., Apiou, J. and Bonnaure-Mallet, M. (2001) Assessment of internalization and viability of Porphyromonas gingivalis in KB epithelial cells by confocal microscopy. Infect Immun 69: 7146-7151.

Inagaki, S., Onishi, S., Kuramitsu, H.K. and Sharma, A. (2006) Porphyromonas gingivalis vesicles enhance attachment, and the leucine-rich repeat BspA protein is required for invasion of epithelial cells by "Tannerella forsythia”. Infect Immun 74: 5023-5028.

Johnson, J.D., Chen, R., Lenton, P.A., Zhang, G., Hinrichs, J.E. and Rudney, J.D. (2008) Persistence of extracrevicular bacterial reservoirs after treatment of aggressive periodontitis. J Periodontol 79: 23052312.

Kuehnel, M.P., Goethe, R., Habermann, A. et al. (2001) Characterization of the intracellular survival of Mycobacterium avium ssp. paratuberculosis: phagosomal $\mathrm{pH}$ and fusogenicity in $\mathrm{J} 774$ macrophages compared with other mycobacteria. Cell Microbiol 3: 551-566.

Lamont, R.J. and Yilmaz, O. (2002) In or out: the invasiveness of oral bacteria. Periodontol 2000 30: 60-69.

Lamont, R.J., Chan, A., Belton, C.M., Izutsu, K.T., Vasel, D. and Weinberg, A. (1995) Porphyromonas gingivalis invasion of gingival epithelial cells. Infect Immun 63: 3878-3885.

Langendijk, P.S., Hagemann, J. and van der Hoeven, J.S. (1999) Sulfate-reducing bacteria in periodontal pockets and in health oral sites. J Clin Periodontol 26: 596-599.

Langendijk, P.S., Hanssen, J.T. and Van der Hoeven, J.S. (2000) Sulfate-reducing bacteria in association with human periodontitis. J Clin Periodontol 27: 943-950.

Langendijk, P.S., Kulik, E.M., Sandmeier, H., Meyer, J. and van der Hoeven, J.S. (2001) Isolation of Desulfomicrobium orale sp. nov. and Desulfovibrio strain NY682, oral sulfate-reducing bacteria involved in human periodontal disease. Int J Syst Evol Microbiol 51: 1035-1044.

Langendijk-Genevaux, P.S., Grimm, W.D. and van der Hoeven, J.S. (2001) Sulfate-reducing bacteria in relation with other potential periodontal pathogens. J Clin Periodontol 28: 1151-1157.

Loubinoux, J., Bisson-Boutelliez, C., Miller, N. and Le Faou, A.E. (2002) Isolation of the provisionally named Desulfovibrio fairfieldensis from human periodontal pockets. Oral Microbiol Immunol 17: 321-323.

Luft, J.H. (1961) Improvements in epoxy resin embedding methods. J Biophys Biochem Cytol 9: 409-411.

Madianos, P.N., Papapanou, P.N., Nannmark, U., Dahlen, G. and Sandros, J. (1996) Porphyromonas gingivalis FDC381 multiplies and persists within human oral epithelial cells in vitro. Infect Immun 64: 660-664.

Meyer, D.H., Sreenivasan, P.K. and Fives-Taylor, P.M. (1991) Evidence for invasion of a human oral cell line by Actinobacillus actinomycetemcomitans. Infect Immun 59: 2719-2726.

Meyer, D.H., Mintz, K.P. and Fives-Taylor, P.M. (1997) Models of invasion of enteric and periodontal pathogens into epithelial cells: a comparative analysis. Crit Rev Oral Biol Med 8: 389-409.

Meyer, D.H., Rose, J.E., Lippmann, J.E. and Fives-Taylor, P.M. (1999) Microtubules are associated with intracellular movements and spread of the periodontopathogen Actinobacillus actinomycetemcomitans. Infect Immun 67: 6518-6525.

Moreira, P.R., Lima, P.M., Sathler, K.O. et al. (2007) Interleukin- 6 expression and gene polymorphism are associated with severity of periodontal disease in a sample of Brazilian individuals. Clin Exp Immunol 148: 119-126.

Mukherjee, S., Soe, T.T. and Maxfield, F.R. (1999) Endocytic sorting of lipid analogues differing solely in the chemistry of their hydrophobic tails. J Cell Biol 144: 1271-1284.

Rowan, F.E., Docherty, N.G., Coffey, J.C. and O'Connel, P.R. (2009) Sulphate-reducing bacteria and hydrogen 
sulphide in the aetiology of ulcerative colitis. Br J Surg 2: 151-158.

Sandros, J., Karlsson, C., Lappin, D.F., Madianos, P.N., Kinane, D.F. and Papapanou, P.N. (2000) Cytokine responses of oral epithelial cells to Porphyromonas gingivalis infection. J Dent Res 79: 1808-1814.

Tardieux, I., Webster, P., Ravesloot, J. et al. (1992) Lysosome recruitment and fusion are early events required for trypanosome invasion of mammalian cells. Cell $\mathbf{7 1}$ : 1117-1130.

Vianna, M.E., Holtgraewe, S., Seyfarth, I., Conrads, G. and Horz, H.P. (2008) Quantitative analysis of three hydrogenotrophic microbial groups, methanogenic archaea, sulfate-reducing bacteria, and acetogenic bacteria, within plaque biofilms associated with human periodontal disease. J Bacteriol 190: 3779-3785.

Watanabe, K., Mikamo, H. and Tanaka, K. (2007) Clinical significance of sulfate-reducing bacteria for ulcerative colitis. Nippon Rinsho 65: 1337-1346.

Weglarz, L., Wawszczyk, J., Orchel, A., Jaworska-Kik, M. and Dzierzewicz, Z. (2007) Phytic acid modulates in vitro IL-8 and IL-6 release from colonic epithelial cells stimulated with LPS and IL-1beta. Dig Dis Sci 52: 93-102.
Willis, C.L., Gibson, G.R., Allison, C., Mac-Farlane, S. and Holt, J.S. (1995) Growth, incidence and activities of dissimilatory sulfate-reducing bacteria in the human oral cavity. FEMS Microbiol Lett 129: 267-272.

Yilmaz, O., Verbeke, P., Lamont, R.J. and Ojcius, D.M. (2006) Intercellular spreading of Porphyromonas gingivalis infection in primary gingival epithelial cells. Infect Immun 74: 703-710.

Yoshida, S. and Sasakawa, C. (2003) Exploiting hostmicrotubule dynamics: a new aspect of bacterial invasion. Trends Microbiol 11: 139-143.

Yumoto, H., Yamada, M., Shinohara, C. et al. (2007) Soluble products from Eikenella corrodens induce cell proliferation and expression of interleukin-8 and adhesion molecules in endothelial cells via mitogen-activated protein kinase pathways. Oral Microbiol Immunol 22 36-45.

Zinkevich, V. and Beech, I.B. (2000) Screening of sulphate-reducing bacteria in colonoscopy samples from healthy and colitic human gut mucosa. FEMS Microbiol Ecol 34: 147-155. 
Copyright of Molecular Oral Microbiology is the property of Wiley-Blackwell and its content may not be copied or emailed to multiple sites or posted to a listserv without the copyright holder's express written permission. However, users may print, download, or email articles for individual use. 